\title{
Field evaluation to some types of termites' baits and its carrier toward activity of Microcerotermes castes.
}

\author{
Sawsan S. Moawad ${ }^{1}$ And Noura J. Al.Otaibi ${ }^{2}$ \\ ${ }^{I}$ Pests and Plant Protection Department, N. R. C. Egypt and Science Faculty - Taif University \\ ${ }^{2}$ Biology department-Science Faculty -Taif University Saudia Arabia
}

\begin{abstract}
Three types of termites' baits (namely, Cardboard-Acacia wood-Toilet soft tissues) and four styles of termites' carrier (two design from transparent plastic container (750ml), plastic sacks and cloth-sack) were tested toward Microcerotermes sp. The cardboard was considered the best bait which had ability to increase the foraging activity (i.e. food consumption, soil translocation and the infestation percentage)and numbers of different termite castes. On other hand, the Plastic carrier (open from bottom and pored side) style and sackcloth were recorded the highest rate of food consumption, soil translocation and increased the efficiency of termites bait.
\end{abstract}

\section{Introduction}

Termites (white ants) live in nests underground, often quite a distance from where you may have found them. Termite 'scouts' leave the nest to forage for food. Termite-Bricks are filled with small replaceable pieces of Oak - timber that is very attractive to termites.By placing traps around your house and garden you provide termites with an easy-to-find food source - once they have found the trap, they move in, seal it up, make it their own.

If the termites are already inside the house or garden or farm then it is time to use baits and traps to monitor and control them. Termites are not lone creatures; in fact they exist in large groups called colonies. These colonies can have up to thousands of termites all working together for one common goal. That goal is mainly food and water. So if one is spotted, one can surely bet that many more are not too far behind ( Faragalla,1983).

Placement of traps and baits is extremely important when trying to eradicate a termite infestation. When beginning, start placing the bait or trap in small condensed spaces. Examples include crawl spaces, attics, closets and other such spots in the home. By placing these weapons against insects in tight spaces one is forcing the termite to come into contact with it. Termites are likely to move around the trap or bait if they are positioned in open spaces. If one is able to locate the colony, then placing the bait or trap near it will do considerable damage to the termite. Try and spot the part of the house where termite are entering this will help locate where the colony resides. Note that many termites burrow underground and chances are they underneath the house. This is especially the case when dealing with subterranean termites (Brian, 1978).

There are different types of termites' baits including paper, cardboard, wood or other acceptable termite cellulose food.The bait is kept inside a plastic bait station. The bait must be good enough to compete with the presence of competing tree roots, stumps, woodpiles and structural wood (LaFage et al., 1973, LaFage et al., 1976 and Akhtar and Sarwar 1995).

The present study was aimed to compare between different baits and its carrier to evaluate their efficacy toward the activity of Microcerotermes sp castes.

\section{Materials and Methods}

I-Effect of some types of baits (food source) on efficiency of termites traps. The experiments were carried out to evaluate efficiency of three types of termites bait namely,(Cardboard-Acacia wood-Toilet soft tissues) under field condition. The experiment area $\left(250 \mathrm{~cm}^{2}\right)$ was equally divided to seven rows and columns $(50 \mathrm{~cm}$ distance between them).The experiment was carried out by plant the tested baits which kept inside plastic carrier (open from bottom and lateral side) at depth $12 \mathrm{~cm}$ under soil.Tested baits were planted and distributed at alternative rows as described in Fig. 1. The tested baits were examined every two weeks for four months to calculate food consumption, soil translocation and infestation percentage. 


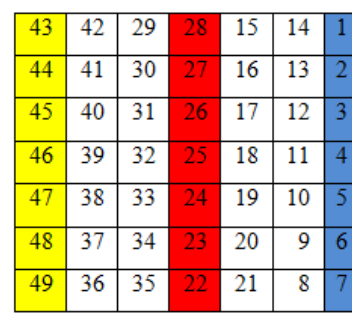

(A)

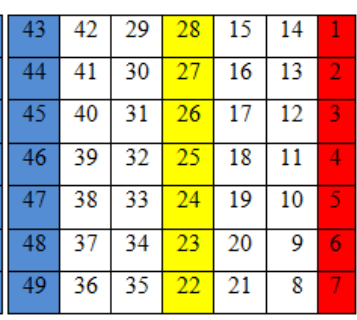

(b)

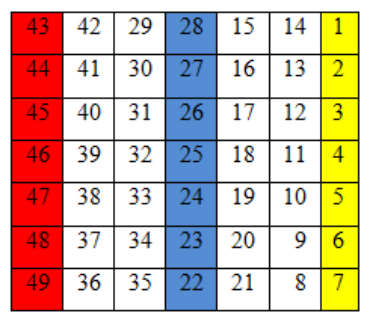

(c)

Empty row $\square$ Acacia wood $\square$ cardboard $\square$ soft tissue

Fig. 1: Preference test design of tested baits under field conditions.

\section{II- Effect of some bait carriers types on the efficiency of termites traps.}

Four types of termites' carrier were evaluated including two design from transparent plastic container $(750 \mathrm{ml})$, plastic sacks and cloth-sack (Fig.2). The design of experiment was done as mention before. Every situation was continuous for one month and then alternate that continues for six months. Examination the traps were occurred for twice time in month to calculate percentage of infestation, foraging activity (food consumption and soil translocation), types of termite castes which collect inside trap.

1- Percentage of infestation $=$ number of infested trap bait/total number of baits in whole area X 100

2- Food consumption were calculated as follows:

Food consumption $(\mathrm{gm})=$. weight of bait before experiment - weight $\quad$ after experiment.

\section{Precaution for both experiments:}

1- Roll of bait was divided to equal weight and size then dried in oven at $105^{\circ} \mathrm{C}$ for 24 hourand after that wet by water to plant in soil (Ahmad 2003).

2- After two weeks, traps were gathered from soil to collect trapped termites (by fine Bruch) and soil translocation inside paper sacks and then dried the reminder parts of baits and soil inside the oven at $105^{\circ} \mathrm{c}$ for $24 \mathrm{hr}$.

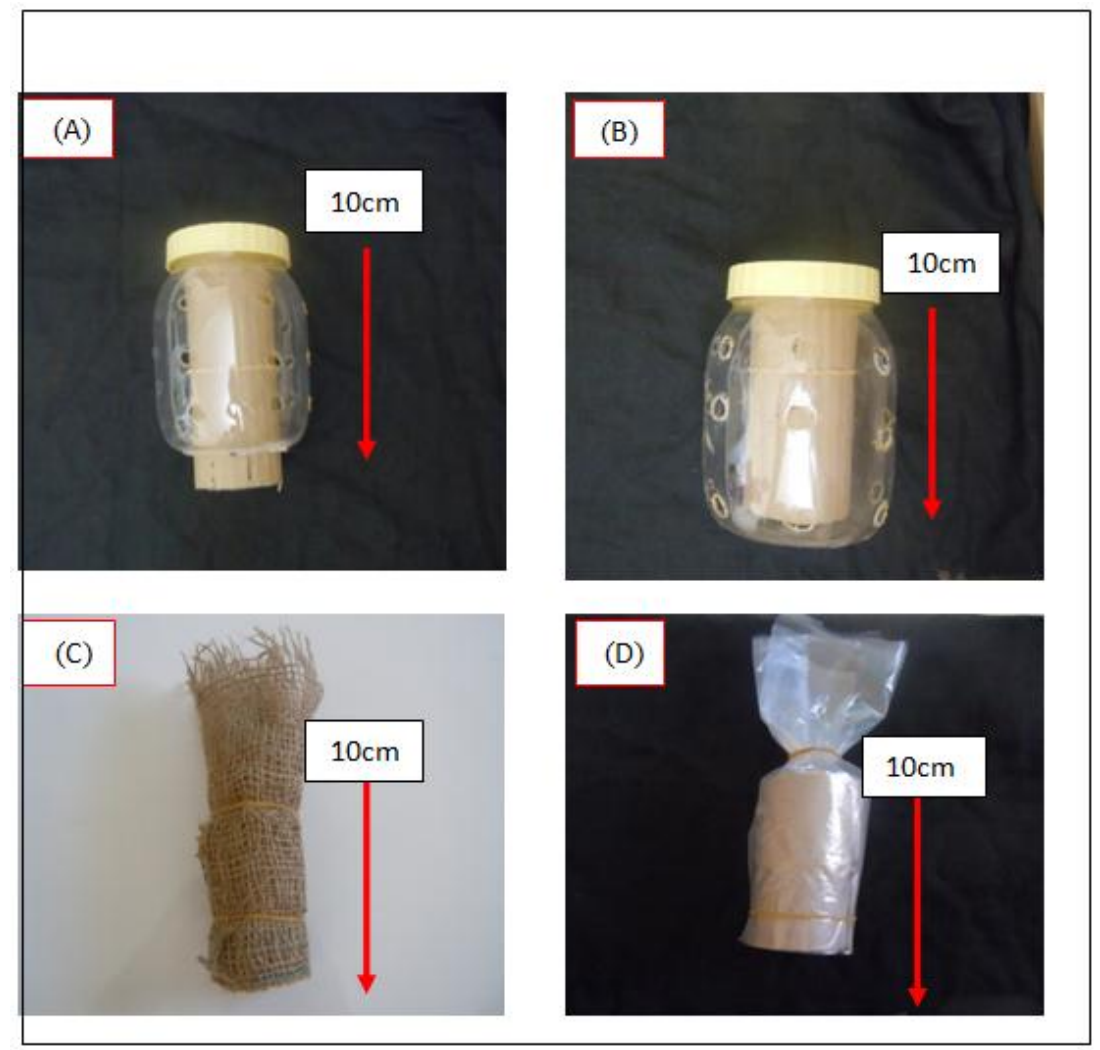

Fig.(2): Design of different bait carrier from (A to D) where:

$\mathrm{A}=$ plastic container with lateral $\&$ basal holes $\mathrm{B}=$ plastic container with lateral holes. $\mathrm{C}=$ sackcloth with lateral \& basal holes. $\mathrm{D}=$ plastic sac with lateral \& basal holes. 


\section{Results and Discussion}

I-Efficiency of some types of baits (food source) as termites trap(foraging activity).

The results in table (1) illustrated that the foraging activity of termites affected by types of baits. So, the cardboard baitselicited highly significant different $(\mathrm{p}<0.01)$ compared to rolls of toilet tissues and Acacia baits. The cardboard baits were recorded the highest rate of food consumption and soil translocation $(5.08 \pm 0.73$ and $9.03 \pm 1.5 \mathrm{gm} / \mathrm{baits})$ compare to toilet baits were $0.71 \pm 0.29$ and $0.89 \pm 0.4 \mathrm{gm} / \mathrm{baits}$ while Acacia baits weren't recorded any foraging activity, except few amount of soil translocation .

Table (1):Effect of some baits (food source) on foraging activity of Microcerotermes sp. in filed. Types of baits Mean of food consumption(g/trap) $\pm \mathrm{SE} \quad$ Mean of soil translocation(g/trap) $\pm \mathrm{SE}$ $(\min -\max ) \quad(\min -\max )$

\begin{tabular}{|c|c|c|}
\hline Cardboard & $\begin{array}{c}5.08 \pm 0.73^{\mathrm{a}} \\
(2.10-7.90)\end{array}$ & $\begin{array}{l}9.03 \pm 1.51^{\mathrm{a}} \\
(3.2-14.4)\end{array}$ \\
\hline Toilet tissues & $\begin{array}{l}0.71 \pm 0.29^{\mathrm{d}} \\
(0.00-2)\end{array}$ & $\begin{array}{c}0.89 \pm 0.4^{\mathrm{b}} \\
(0.00-2.8)\end{array}$ \\
\hline Acacia wood & $\begin{array}{l}0.00^{\mathrm{d}} \\
0.00 \\
\end{array}$ & $\begin{array}{c}0.1 \pm 0.08^{\mathrm{b}} \\
(0.00-0.7)\end{array}$ \\
\hline Statistical analysis & $\begin{array}{c}\text { L.S.D } D_{0.05}=1.3 \\
\text { L.S. } D_{0.01}=1.76\end{array}$ & $\begin{aligned} \text { L.S.D } & \\
\text { L.S. } & =2.6 \\
0.01 & =3.55\end{aligned}$ \\
\hline
\end{tabular}

Means with the same letters have no significant difference $(\mathrm{p}>0.05)$.

On the other hand, the most termite castes (worker, solider and larvae) of Microcerotermes sp attracted toward the cardboard baits especially in August month while toilet tissues baits collected only worker caste as described in Table 2. So, the cardboard baits recorded the highest infestation level reaching to $69.84 \%$ compared to toilet $22.21 \%$ and Acacia wood $4.77 \%$ as show at Fig 3.

From weeklyinvestigationof the baits noticed that allcardboard bait sides infested by termite castes while infestation of toilet tissues baits occurred only at inner margin which buried into soil as show in Fig (4).

Table(2): Types of castes of Microcerotermes sp that attracted to test baits under field condition.

\begin{tabular}{|c|c|c|c|c|c|c|c|c|}
\hline month & Type bait & 1 & 2 & 3 & 4 & 5 & 6 & 7 \\
\hline \multirow[t]{3}{*}{ Jun. } & Cardboard & $\mathrm{W}$ & $\mathrm{W}$ & - & - & - & - & - \\
\hline & Toilet tissues & - & - & - & - & - & - & - \\
\hline & Acacia wood & - & - & - & - & - & - & - \\
\hline \multirow[t]{3}{*}{ Jul. } & Cardboard & $\mathrm{w}+\mathrm{s}$ & $\mathrm{w}$ & $w+s+1$ & $\mathrm{~W}$ & - & - & - \\
\hline & Toilet tissues & - & - & - & - & - & - & - \\
\hline & Acacia wood & - & - & - & - & - & - & - \\
\hline \multirow[t]{3}{*}{ Aug. } & Cardboard & $\mathrm{W}$ & $\mathrm{w}+\mathrm{s}$ & $w+s+n+1$ & $\mathrm{w}+\mathrm{s}$ & $w+s+n+1$ & $\mathrm{w}+\mathrm{s}$ & $\mathrm{w}+\mathrm{s}+\mathrm{n}+\mathrm{l}$ \\
\hline & Toilet tissues & $\mathrm{W}$ & - & - & - & - & - & - \\
\hline & Acacia wood & - & - & - & - & - & - & - \\
\hline \multirow[t]{3}{*}{ Sep. } & Cardboard & $\mathrm{W}$ & $\mathrm{W}$ & $w+s$ & $\mathrm{w}+\mathrm{s}$ & $\mathrm{w}+\mathrm{s}$ & $w+s$ & $\mathrm{w}+\mathrm{s}$ \\
\hline & Toilet tissues & $\mathrm{W}$ & $\mathrm{W}$ & $\mathrm{W}$ & $\mathrm{W}$ & - & - & - \\
\hline & Acacia wood & $\mathrm{W}$ & - & - & - & - & - & - \\
\hline \multirow[t]{3}{*}{ Oct. } & Cardboard & $\mathrm{w}+\mathrm{s}$ & $\mathrm{w}$ & $w+s$ & $\mathrm{w}+\mathrm{s}$ & $\mathrm{w}+\mathrm{s}$ & $\mathrm{w}$ & $\mathrm{w}+\mathrm{s}$ \\
\hline & Toilet tissues & $\mathrm{W}$ & $\mathrm{W}$ & $\mathrm{W}$ & $\mathrm{w}+\mathrm{s}$ & $\mathrm{W}$ & $\mathrm{w}$ & $\mathrm{W}$ \\
\hline & Acacia wood & $\mathrm{W}$ & $\mathrm{w}$ & - & - & - & - & - \\
\hline
\end{tabular}

**w: worker $\mathrm{s}:$ soldier $\mathrm{n}:$ nymph 1 : larva

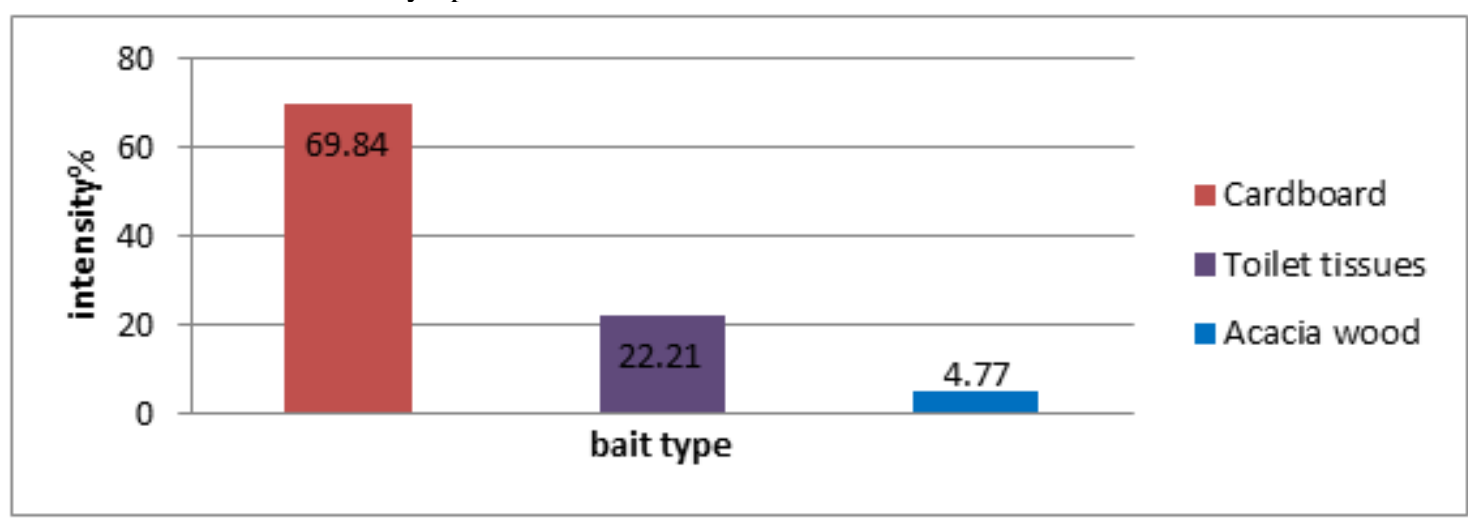

Fig.(3): Frequency occurrence of Microcerotermes sp. at tested termite baits. 


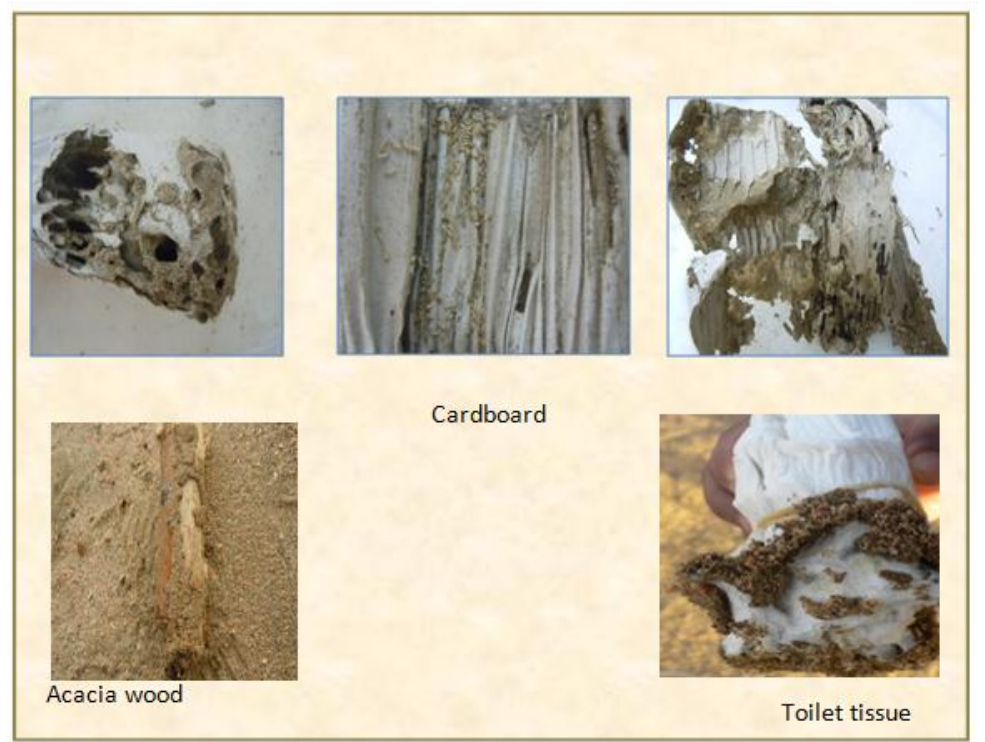

Fig. 4: Symptoms of infectionoftest termites baits.

From the obtained results, it could be concluded that there were variations between the three types of tested baits where the cardboard bait was the best preferable one to Microcerotermis $s p$ termites. There are many factors were control in foraging activity of termites as chemical constituentsof baits as mentioned by Haris, 1961; Bernklauet al., 2005; Cheng et al., 2007 and Moawadet al., 2012. On the other side, the variation in degree of bait preference might be related to its'physical structure; the cardboard baits consisted of two layers; upper one was smooth and inner one was sinuosity which might acted as termites tunnel thailentatissye termites in soil, beside it wasn't adhered when exposed to moisture and dryness. While rolls of toilet baits were mightily adhered its layers when exposed to moisture and dryness and that prevented the termites to penetrate it; so it was noticed that toilt bait attracted only into inner margin. Ahmad,1997 and Abd El-latif ,2003 used rolls of cardboard and toilet tissues to measurement foraging activity of termites. While, La Fage et al.,1973, Said, 1979and Badawi et al., 1984 used rolls of toilet tissues to measurement foraging activity of termites.

Although Acassia wood tree considered one of preferable host to termites, it elicited the lowest attraction to termites as baits. It might be related to many factors as insufficient amount of fungi which analysis wood to simplest form thatlet's termites to penetrate and consumed it (Smythe et al., 1971 ; Carter \& Smythe, 1974 ;Nagnan\& Clement, 1990 and Cornelius et al.,2004).

\section{II- Effect of some type of bait carriers on the efficiency of termites traps.}

Foraging activity of termites and percentage of bait infestation were affected by bait carrier cleared in table 3 . Plastic carrier (open from bottom and pored side) and sackclothwere recorded the highest rate offood consumption and soil translocation reached to $18.43 \pm 0.95,13.83 \pm 0.95$ and $13.52 \pm 1.19,10.62 \pm 0.6 \mathrm{gm} /$ infested trap respectively, compared to carriers of plastic containers (with lateral holes without base.) and plastic sack with lateral holes without basewith an average food consumption and soil translocation within carriers to10.91 $\pm 1.74,7.18 \pm 1.33$ and $13 \pm 2.86,8.61 \pm 1.76 \mathrm{gm} /$ infested trap respectively.

Table(3): Effect of some type of bait carriers on foraging activities of Microcerotermes sp. under field condition .

\begin{tabular}{|c|c|c|}
\hline Types of baits carriers & $\begin{array}{c}\text { Mean of food consumption(g/infested trap) } \\
\pm \text { SE } \\
(\min -\max )\end{array}$ & $\begin{array}{c}\text { Mean of soil translocation }(\mathrm{g} / \\
\text { infested trap) } \pm \mathrm{SE} \\
(\min -\max )\end{array}$ \\
\hline $\begin{array}{l}\text { plastic container with lateral holes } \\
\text { without base. }\end{array}$ & $\begin{array}{l}13.83 \pm 0.95^{\mathrm{a}} \\
(9.7-20.3)\end{array}$ & $\begin{array}{l}18.43 \pm 0.95^{\mathrm{a}} \\
(12.9-22.3)\end{array}$ \\
\hline $\begin{array}{l}\text { plastic container with lateral holes with } \\
\text { base. }\end{array}$ & $\begin{array}{l}7.18 \pm 1.33^{\mathrm{bs}} \\
(0.00-12.4)\end{array}$ & $\begin{array}{l}10.91 \pm 1.74^{\mathrm{cs}} \\
(0.00-16.6)\end{array}$ \\
\hline $\begin{array}{c}\text { plastic sack with lateral holes without } \\
\text { base. }\end{array}$ & $\begin{array}{l}8.61 \pm 1.76^{\mathrm{bs}} \\
(0.00-14.3)\end{array}$ & $\begin{array}{c}13 \pm 2.86^{\mathrm{bs}} \\
(0.00-23.8)\end{array}$ \\
\hline sackcloth with lateral holes without base . & $\begin{array}{l}10.62 \pm 0.6^{\mathrm{as}} \\
(7.5-13.2)\end{array}$ & $\begin{array}{l}13.52 \pm 1.19^{\text {as }} \\
(7.2-17.8)\end{array}$ \\
\hline Statistical analysis & $\begin{aligned} \mathrm{LSD}_{0.05} & =3.54 \\
\mathrm{LSD}_{0.01} & =4.73\end{aligned}$ & $\begin{aligned} \mathrm{LSD}_{0.05} & =5.25 \\
\mathrm{LSD}_{0.01} & =7.03\end{aligned}$ \\
\hline
\end{tabular}

Means with the same letters have no significant difference ( $(p>0.05)$. 
On other view, Table 4 were cleared the types of termite castes were recorded inside tested modified trap. The baits were placed inside plastic carrier (open from bottom and pored side) were considered the best one so it attracted different termites castes like as worker, soldiers, nymphs and larvae in October and November months, while the nymph castes onlydisappearedin December and January; while in the month of February and March, theworker and soldiers did not appear.while the carrier prepared from plastic bags were recorded the lowest efficiency to baits to attract termite castes.So, the plastic container with lateral holes without base and sackcloth with lateral holes without base were recorded the highest infestation level reaching to 58.69\% and $57.10 \%$ respectively,compared to plastic container with lateral holes without base $25.33 \%$ and plastic sack with lateral holes without base $38.03 \%$ as show at Fig 5 .

Table(4): Efficiency of some bait carriers on hunt the termite castes.

\begin{tabular}{|c|c|c|c|c|c|c|c|c|}
\hline \multirow[b]{2}{*}{ Month } & \multirow{2}{*}{$\begin{array}{l}\text { Type of } \\
\text { carrier }\end{array}$} & \multicolumn{7}{|c|}{ Number of trap in row } \\
\hline & & 1 & 2 & 3 & 4 & 5 & 6 & 7 \\
\hline \multirow{4}{*}{ Oct. } & $\mathrm{A}$ & $w+s+n+1$ & $w+s$ & $w+s$ & $\mathrm{w}$ & - & - & - \\
\hline & $\mathrm{B}$ & $\mathrm{W}$ & $w+s$ & - & - & - & - & - \\
\hline & $\mathrm{C}$ & $w+s+n$ & $\mathrm{~W}$ & $w+n$ & $w+s+n$ & $w+s+1$ & - & - \\
\hline & $\mathrm{D}$ & - & - & - & - & - & - & - \\
\hline \multirow{4}{*}{ Nov. } & $\mathrm{A}$ & $w+s+n+1$ & $w+s$ & $w+s$ & $\mathrm{w}+\mathrm{s}$ & - & - & - \\
\hline & $\mathrm{B}$ & $\mathrm{w}+\mathrm{s}+\mathrm{l}$ & $\mathrm{W}$ & - & - & - & - & - \\
\hline & $\mathrm{C}$ & $\mathrm{w}+\mathrm{s}$ & $w+s$ & $\mathrm{w}$ & $\mathrm{w}$ & - & - & - \\
\hline & $\mathrm{D}$ & $\mathrm{W}$ & $\mathrm{w}$ & $\mathrm{w}$ & $\mathrm{W}$ & - & - & - \\
\hline \multirow{4}{*}{ Dec. } & $\mathrm{A}$ & $\mathrm{w}+\mathrm{s}+\mathrm{l}$ & $w+s$ & $w+s$ & $\mathrm{~W}+\mathrm{s}$ & - & - & - \\
\hline & B & $w+s+n$ & $\mathrm{~W}$ & - & - & - & - & - \\
\hline & $\mathrm{C}$ & $\mathrm{w}+\mathrm{s}$ & $w+s$ & $w+s$ & $\mathrm{~W}$ & - & - & - \\
\hline & $\mathrm{D}$ & $w+s$ & $w+s$ & $w+s$ & $w+s$ & $\mathrm{~W}$ & $\mathrm{~W}$ & - \\
\hline \multirow{4}{*}{ Jan } & $\mathrm{A}$ & $\mathrm{w}+\mathrm{s}+\mathrm{l}$ & $w+s$ & $w+s$ & $w+s$ & $\mathrm{w}+\mathrm{s}$ & - & - \\
\hline & B & $\mathrm{w}$ & $\mathrm{w}$ & $\mathrm{w}+1$ & - & - & - & - \\
\hline & $\mathrm{C}$ & $w+s$ & $w+s$ & $w+s$ & $w+s$ & $\mathrm{~W}$ & - & - \\
\hline & $\mathrm{D}$ & $w+s$ & $w+s$ & $\mathrm{~W}$ & $\mathrm{~W}$ & - & - & - \\
\hline \multirow{4}{*}{ Feb. } & A & $\mathrm{w}$ & $w+s$ & $w+s$ & $w+s$ & $\mathrm{w}$ & $w+s$ & - \\
\hline & B & $\mathrm{W}$ & - & - & - & - & - & - \\
\hline & $\mathrm{C}$ & $w+s$ & $\mathrm{~W}$ & $\mathrm{w}$ & $\mathrm{W}$ & - & - & - \\
\hline & $\mathrm{D}$ & $\mathrm{W}$ & $\mathrm{W}$ & - & - & - & - & - \\
\hline \multirow{4}{*}{ Mar. } & A & $w+s$ & $\mathrm{~W}$ & - & $w+s$ & $\mathrm{w}$ & - & - \\
\hline & B & $\mathrm{W}$ & $\mathrm{W}$ & - & - & - & W & - \\
\hline & $\mathrm{C}$ & $\mathrm{w}+\mathrm{s}$ & $\mathrm{w}$ & $w+s$ & - & $w+s$ & $w+s$ & - \\
\hline & D & $\mathrm{w}$ & - & $\mathrm{w}$ & $\mathrm{W}$ & - & - & - \\
\hline
\end{tabular}

$\mathrm{A}=$ plastic container with lateral holes without base, $\mathrm{B}=$ plastic container with lateral holes with base $. \mathrm{C}=$ sackcloth with lateral holes without base., $\mathrm{D}=$ plastic sack with lateral holes without base .

${ }^{*} *_{\mathrm{w}}$ : worker , s : soldier , $\mathrm{n}:$ nymph , $1:$ larve

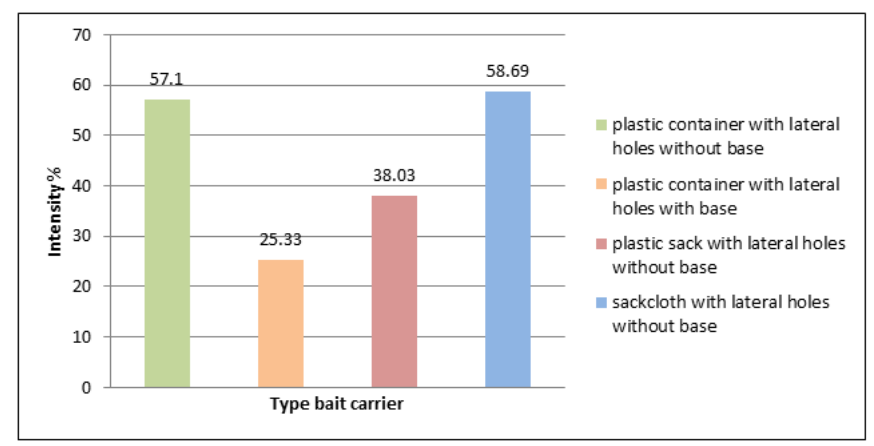

Fig.(5): Frequency of Microcerotermes sp. occurrences on different types of termite traps.

From the obtained results, It was cleared that the efficiency of termites baits affected by its' carrier. Klotz et al., 1997mentioned that typical termite traps must be followed certain regulations to be able considered itsattractive or unpalatable to termites. They considered that baitcarriers, one of the most important factors which affect on the efficiency of the termites' trap. Therefore, many researchers are interested in finding suitable carriers which had ability to increase the efficiency of the termites' trap and protectedthe grafts from damage due to environmental factors such as rain or wind, and others. 
El-Sebay, 1991 had obtained on patented prize as a result of the design of a termites' trap under the ground which composed of corrugated cardboard covered from the outside with a layer of polythene installed ring rubber bearer taste that were considered the best way to increase trap efficacy. Ahmed, 1997 confirmed that the cardboard as termite baits which holder inside nylon tubing (PVC) had ability to estimate the rate of consumption of food , transportation and a number of termite (Anacanthotermis ochraceus) attraction.

Su et al., 1991 surrounded the termite' baits by wooden collars of polyvinyl chloride (PVC) ( diameter $17 \mathrm{~cm}$ height and $15 \mathrm{~cm}$ ) to study the census termites under the ground of type C. formosanus. Generally, It is very important to design termite trap, have to select the most effect bait and holder it inside suitable carrier to achieve their goal.

\section{References}

[1]. Abd El-Latif N A. (2003): Ecological and control studies on certain subterranean termite species. Ph. D. Thesis, Fac. of Agric. Cairo Univ., pp267.

[2]. Ahmed, H. M. (1997): Ecoloical studies and control of harvester subterranean termite Anacanthotermesochraceus (Burm.) at El Fayoum governorate. M. Sc. Thesis, Fac. Agric., Cairo Univ. El Fayoum branch,77p.

[3]. Ahmed, H. M. (2003): Ecological and control studies on subterranean termites under Fayoum conditions. Ph. D. Thesis, Fac. of Agric. Cairo Univ. El- Fayoum branch, pp140.

[4]. Akhtar, M.S. and Sarwar, G. (1995): The foraging activity of subterranean termites in desert zone of Pakistan. Pakistan, J. Zool., 27 (4):329-336

[5]. Badawi, A. ;Faragalla, A. A. and Dabbour, A. (1984): The distribution of foraging territories and densities of colonies of two species of subterranean termites in AL-Kharj oasis, central region of Saudi Arabia. Z. angew. Entom. 97 (4): 387-393.

[6]. Bernklau, E. J.; Fromm, E. A. ; Judd, T. M. and Bjostad, L. B.(2005): Attraction of subterranean termites (Isoptera) to carbon dioxide. J. $\quad$ Econ. Entomol., 98(2): 476-484.

[7]. Brian, M. V. (1978): Production ecology of ants and termites. Cambridge Univ. Press. London . 409 p.

[8]. Carter, F. L. and Smythe, R. V. (1974): Feeding and survival responses

[9]. Reticulitermesflavipes(Kollar) to extractives of woods from 11Coniferous genera .Holzforschung, 28: 41 - 45 Cheng, S.S.; Wu, C.L.; Chang, H.T. and Chang, S.T.(2007): Anti-termitic activities of essential oils from coniferous trees against Coptotermesformosanus.Bioresource Technology, 98: 456-459.

[10]. Cornelius, M. L. ;Bland, J. M. ; Daigle, D. J. ; Williams, K. S. ; Lovisa, M. P Connick, W. J. and Lax, A. R. (2004): Effect of a Lignin-Degrading Fungus on Feeding Preferences of Formosan Subterranean Termite Ioptera: Rhinotermitidae) for Different Commercial Lumber. J.Econ.Entomol.97(3): 1035 . - 1025

[11]. El-Sebay, Y. (1991): A modified El-Sebay trap for subterranean termites fourth Arab. Congress of Plant Protection. Cairo, Egypt. 245-247.

[12]. Faragalla, A. A. (1983): Termite problems in Saudi Arabian ecosystem. Sociobiology 8(2):119 - 125

[13]. Harris, W. V. (1961): Termites their recognition and control. Longmans,London,187p

[14]. Klotz, J. H.; Reid, B.L. and Williams, D.F. (1997):Laboratory and field techniques for development and evaluation of bait for urban pest ants. Recent Res. Devel. Entomol. 1: 83-92.

[15]. La Fage, J. P.; Haverty , M. I. And Nutting, W. L. (1976): Environmental

[16]. factors correlated with the foraging behavior of a desert subterranean termite, Gnathamitermesperplexus(Banks) (Isoptera: Termitidae). Sociobiology, 2(2):155-167.

[17]. La Fage, J. P. ;Nutting,W. L. and Haverty, M. I. (1973) : Desert subterranean termites a method for studying foraging behavior. Environ. Entomol.,(2): 954-956.

[18]. Moawad, S. S. ; Al-Barty, A. M. and AL- Otaibi, N. J. (2012) : Behavioural Response of Anacanthotermesochraceus towards Some Baits and Volatile Oils . Journal of Agricultural Science and Technology B 2 (2012) 1279-1286.

[19]. Nagnan, P. and Clement, J. L. (1990):Terpenes from the maritime pine PinusPinaster:toxins for subterranean termites of the genus Reticulitermes (Isoptera :Rhinotermitidae). Biochemical Systematic and Ecology, 18: 13 - 16 .

[20]. Said, W. A., (1979): Ecological and toxicological studies on (Family :Hodotermitidae ). M. Sc. Thesis Fac. Agric. Ain Shams Univ., pp. 128.

[21]. Smythe, R.V. ; Carter, F. L. and Baxter, C. C. (1971): Influence of wood decay On feeding and survival of the eastern subterranean termites ReticulitermesFlavipes(Isopera : Rhinotermitidae) . Ibid, $64: 59-62$.

[22]. Su, N.-Y.; Ban, P. M. and Scheffrahn , R. H. (1991): Suppression of foraging populations of the formosan subterranean termite (Isoptera: Rhinotermitidae) by field applications of a slow-acting toxicant bait. J. Econ. Entomol ., 84(5):1531-1925. 